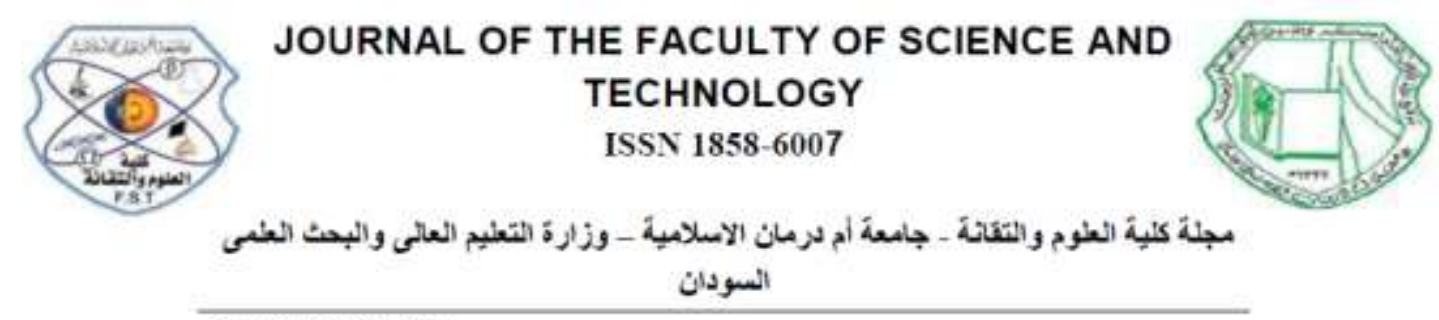

Research article

\title{
Genesis of Gold Deposit in Um Trambishi Area, NE Atbara, Sudan
}

\author{
Moa'awia Adam Mohamedai ${ }^{1}$, Osman Mohammed Elhassan ${ }^{2}$ \\ ${ }^{1}$ E-mail: moawiamohameday@ hotmail.com \\ ${ }^{2}$ E-mail: osmanmetar@yahoo.com
}

\begin{abstract}
Um Trambishi area consists of volcano-sedimentary sequence intruded by syntectonic pluton of granitoids composition with marginal fissures injected by aplite, had been subjected to dynamic metamorphism and obliterated by recrystallization forming different rock units varying in composition, forming greenschist terrains. These are an assemblage of recrystalline schists, meta-acid, cataclastic tonalite, granodiorites, meta-andesite, chlorite schists, quartzite, marble, metabanded chert, together with two generations of unmineralized deformed and undeformed white quartz, which are oriented mainly in E-W and N-S direction following faults trend. The area is subjected to four deformational phases of brittle-ductile transition. The metamorphic grade is Green Schist Facies. The alteration around the endo-contact zone is characterized by minerals: albite, chlorite, epidote, sericite, carbonate and kaolin with anomalous $\mathrm{Au}=0.91 \mathrm{ppm}$, $\mathrm{Ag}=1.75 \mathrm{ppm}, \mathrm{As}=44.6 \mathrm{XRF}, \mathrm{Co}=15.70 \mathrm{XRF}, \mathrm{V}=65 \mathrm{XRF}, \mathrm{Ti}=4796 \mathrm{XRF}, \mathrm{Cr}=23 \mathrm{XRF}, \mathrm{Sr}=269 \mathrm{XRF}$, and base metals $\mathrm{Pb}=1.51 \mathrm{ppm}, \mathrm{Zn}=22.02 \mathrm{ppm}$ and $\mathrm{Cu}=13.59 \mathrm{ppm}$. The first phase of hydrothermal solution carrying gold is related to the magmatic high temperature associated with granitoidal intrusions, deposited into the planar fabric S1 and has a characteristic signature of hypothermal processes .The second mode of occurrence is the regeneration of auriferous quartz stringers filling into the tectonic fissures trending $340^{\circ}$ and oblique to S1 as a result of D3 (Keraf Shear Zone) and has a characteristic signature of mesothermal processes.
\end{abstract}

Keywords: Volcano-sedimentary sequence; Granitoids; Mineralization; Shear zone

\section{Introduction}

Um Trambishi Area is located in River Nile State, $14 \mathrm{Km}$ NE of Abidyia, bounded by latitudes $18^{\circ} 14^{\prime} 9^{\prime \prime} \mathrm{N}\left(2016610\right.$ UTM) - 18 $8^{\circ} 12^{\prime}$ 58" N (2012775 UTM) and longitudes $34^{\circ} 4^{\prime}$ 58"E (614500 UTM) - 34º 4' 10"E(613090 UTM) (Fig.No.1).
The geneses of gold deposits in UmTrambishi Area are related to the total geological environment. Tectonic and metallogeny provide a helpful scientific basis to define gold mineralization. The gold formed synchronously with the late stages of still ongoing regional deformation. The aim 
is to use geological characteristics and geochemical signature of the trace elements within the alteration zone to identify the origin of the hydrothermal fluid carrying the gold.

\section{Geological and Tectonic Setting}

The area is a part of Arabian-Nubian Shield which consists of metavolcano-sedimentary rocks cut by syntectonic pluton of granitoidal composition. This assemblage had been subjected to dynamic metamorphism and obliterated by recrystallization of rock forming units variable in composition forming greenschist terrains of metavolcanic-metasedimentary rocks.

Syntectonic granodiorites and tonalites intrude the metavolcanic-metasedimentary rocks with a marginal fissures injected by a meta-acid (aplite).This succession is corresponding to the mid Pan African
Trondhjemite- Tonalite - Granodioritic suite (Abdel Salamet al., 1998) which marks widespread emplacement of 690-720Ma intrusive rocks(Fig.No.2).

Four deformational phases can be recognized in the study area; the different phases(D1-D4) not necessary represent separated events but might be transitional and belong to one single deformational episode which is believed to beKeraf Shear Zone.

Two generations of unmineralized deformed and undeformed white quartz are oriented mainly in E-W and N-S direction following trend of faults.

Mineralized white quartz veinlets (Photo No.1) are associated with the emplacement of the granitoids intrusion while the mineralized white to faint grey quartz stringers trending $340^{\circ}$ are related to shearing (Photo No.2). 


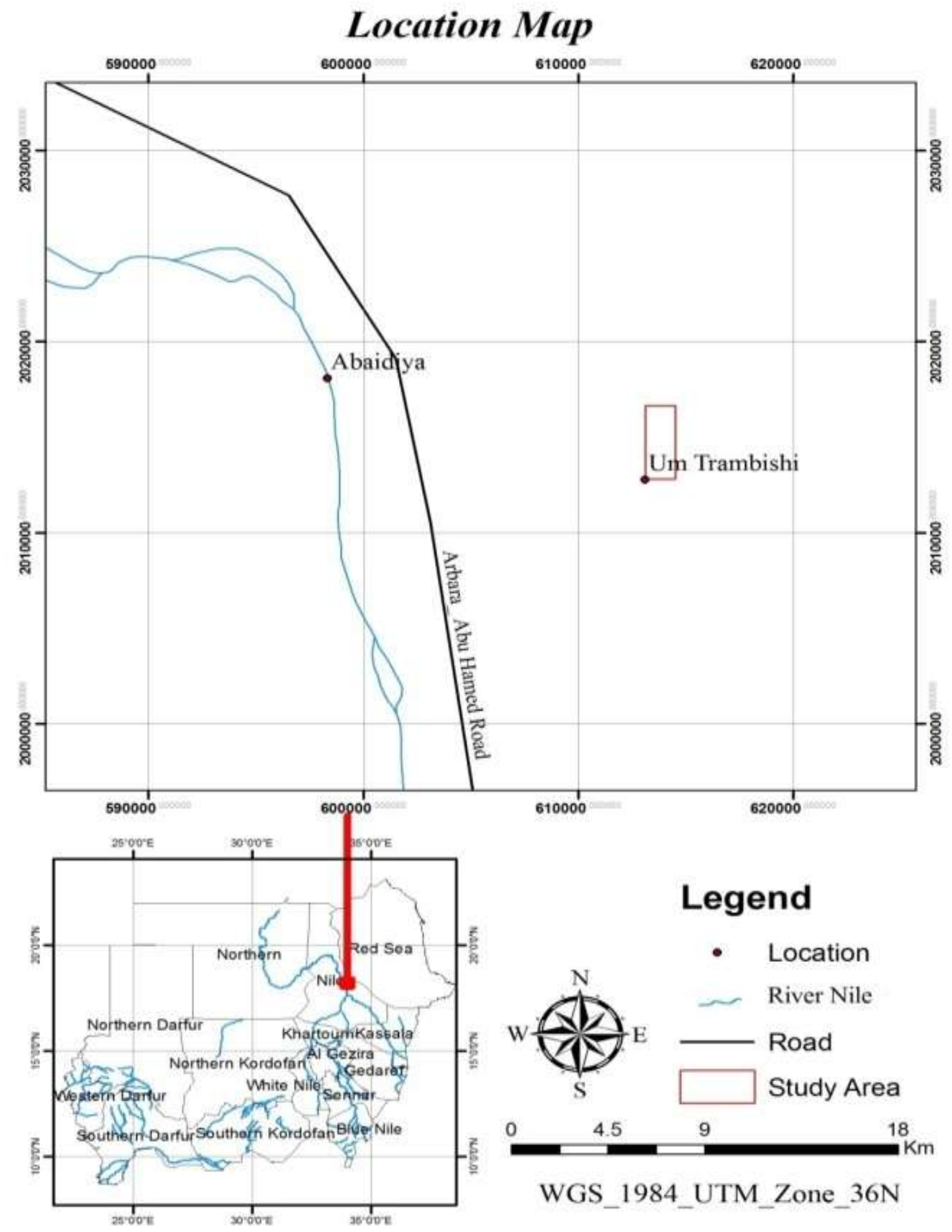

Fig.No.1: Location map 


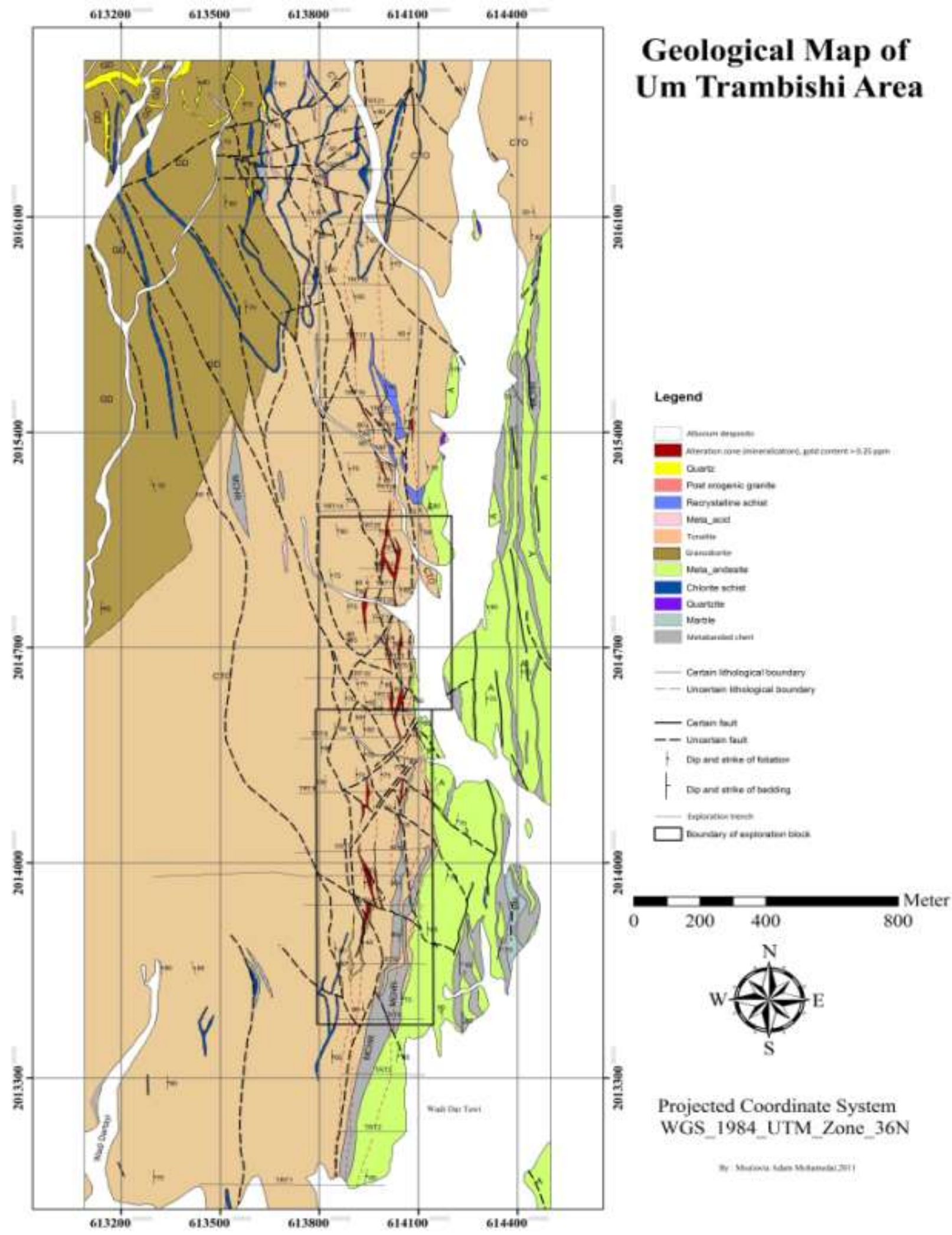

Fig.No.2: Geological map of Um Trambishi Area 


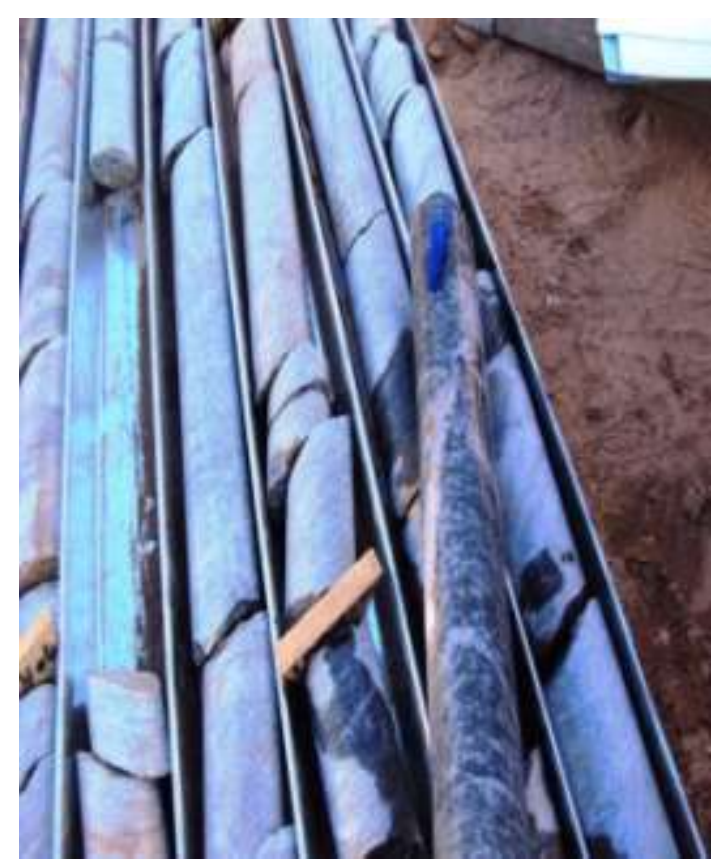

PhotoNo.2: Quartz veinlets and stringer

\section{Discussion}

\section{Geochemical Data and Direct Criteria}

Sampling included used chip samples, systematic trench sampling and core samples.

Thirty two chip samples were collected from the quartz veins in the endo- exo-contact zoneandother lithological units, 7817 channel samples across the strike of the alteration zone, were collected along the northern wall of the trench in success interval of approximately $1.0 \mathrm{~m}$ and2,319 core samples of the drill edboreholes core samples were collected from drilled boreholes. These samples passed systematic reduction of mass and grain size at the Laboratory of Exploration and Development Department ofRida Mining Company.Were reduced by crushing to minus 19 millimeters; the resultant wassplitted until $200 \mathrm{gm}$ weight. The $200 \mathrm{gm}$ weighted

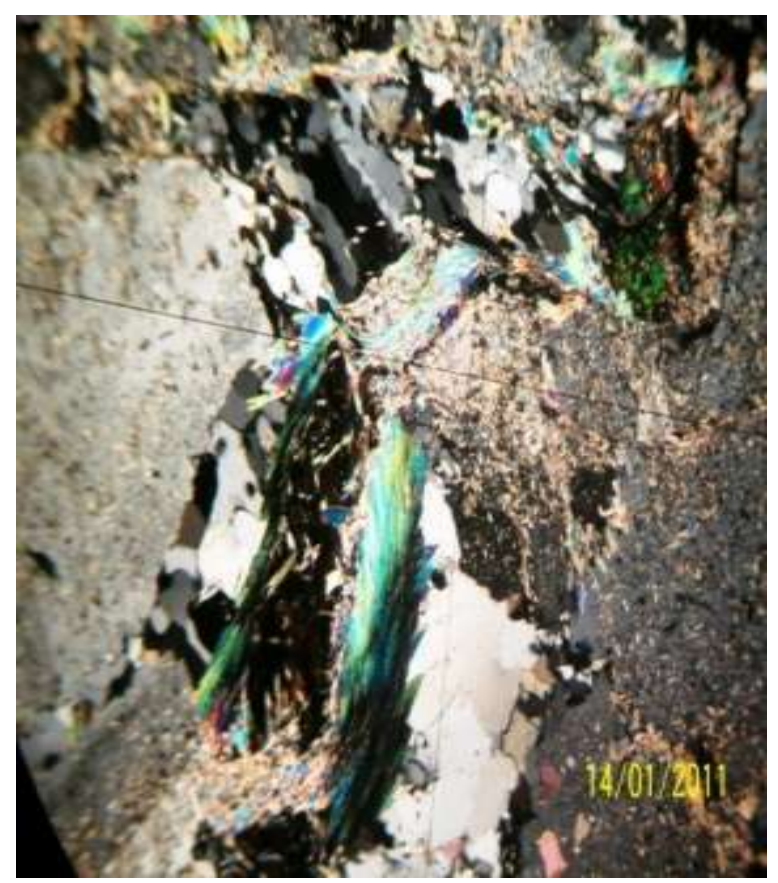

photo No.1: Quartz veinlets in tonalite; x25 in tonalite

samples grinded to minus 80 micron which became portion for analytical procedures were to be analyzed for gold. The samples were decomposed by treatment with aqua regia (3HCl:1HNO3). Gold is extracted from the solution into a solution of tricaprylyl methyl ammonium chloride (Aliquat 336) in di-isobutyl ketone (DIBK). The gold is determined by aspirating the organic phase in the Atomic Absorption Spectrometry (AAS) unit. Selected trench (TRT5, TRT5A and TRT13) samples within the oxidation zone and core(TDDH-1, 2, 3, 4, 7 and 9) samples of the intersected mineralization below the oxidation were passed through X-ray Fluorescence (XRF) for trace elements determination. The analytical results are displayed in Table No.1. The chloritization is probably linked with the hydrothermal solution with sericitization, silicification and 
probalization (albite, chlorite, epidote, sericite and carbonate). Kaolinization is found within the alteration zone as a process of oxidation (supergene enrichment) indicating high sulphidation. Giles (1972) andSchilling (1972), explain that, the content or ratio of elements in minerals can also be used to identify types of ores. In low and high sulphidation state, generally the ratio $\mathrm{Ag} / \mathrm{Au}$ reach 0.2 to 2.0 (John, 2001), relating this to the data obtained, the ratio of $\mathrm{Ag} / \mathrm{Au}$ is 2.83 with a chemical signature of $\mathrm{Au}, \mathrm{Ag}, \mathrm{As}, \mathrm{Co}, \mathrm{V}$, Ti, Cr, Sr, base metals $\mathrm{Pb}, \mathrm{Zn}$ and $\mathrm{Cu}$. Thus, the hydrothermal solution may take place after the crystallization of felsic dyke and have a characteristic signature of hypothermal, mesothermal successive stages of hydrothermal processes. The first mode of occurrence (hypothermal) is related to the granitoids intrusion (BadrelDin Khalil, 1973) while the second mode of occurrence (mesothermal) is related to Keraf Shear Zone (KSZ), have no link to magmatism as a carrier phase, generating hydrothermal white to faint grey quartz stringers, filled into the tectonic fissures trending $\mathrm{N}$ to NNW, forming a network of stringer lodes (shear zone hosted gold).

Table No.1: Analysis of trace elements

\begin{tabular}{|c|c|c|c|c|c|c|c|c|c|c|c|c|c|c|c|}
\hline \multirow{2}{*}{ ID } & Sample & $\mathbf{A u}$ & $\mathbf{A g}$ & $\mathbf{F e}$ & $\mathbf{C u}$ & $\mathbf{Z n}$ & $\mathbf{P b}$ & $\mathbf{A s}$ & $\mathbf{T i}$ & $\mathbf{V}$ & $\mathbf{C r}$ & $\mathbf{C o}$ & $\mathbf{Z r}$ & $\mathbf{T h}$ & $\mathbf{S r}$ \\
\cline { 2 - 13 } & $\mathbf{I D}$ & $\mathbf{p p m}$ & $\mathbf{p p m}$ & $\mathbf{\%}$ & $\mathbf{p p m}$ & $\mathbf{p p m}$ & $\mathbf{p p m}$ & $\mathbf{p p m}$ & $\mathbf{X R F}$ & $\mathbf{X R F}$ & $\mathbf{X R F}$ & $\mathbf{X R F}$ & $\mathbf{X R F}$ & $\mathbf{X R F}$ & $\mathbf{X R F}$ \\
\hline TRT5 & 42082 & 0.23 & - & 3.86 & 14.68 & 14.57 & 1.36 & 5.93 & 2213 & 46 & 65 & 9.9 & 144 & 8 & 137 \\
\hline TRT5 & 42088 & 0.01 & - & 7.02 & 11.96 & 20.16 & 2.37 & 13.13 & 4821 & 89 & 96 & 18.4 & 269 & - & 219 \\
\hline TRT13 & 24236 & 0.26 & - & 8.25 & 15.76 & 20.47 & - & 3.64 & 5154 & 97 & 81 & 16 & 264 & 8 & 138 \\
\hline TRT5A & 42002 & 1.62 & - & 5.33 & - & 20.78 & 1.53 & 10.76 & 2984 & 71 & 51 & 10.3 & 116 & 8 & 169 \\
\hline $\begin{array}{c}\text { TDDH- } \\
01\end{array}$ & 72490 & 0.91 & 1.75 & 9.21 & 13.59 & 22.02 & 1.51 & 18.9 & 8160 & 98 & - & 24.00 & 230 & 8 & 277 \\
\hline $\begin{array}{c}\text { TDDH- } \\
03\end{array}$ & 71999 & 11.69 & - & 7.91 & 12.5 & 22.64 & - & 19.1 & 4796 & 65 & 23 & 15.70 & 277 & 11 & 269 \\
\hline $\begin{array}{c}\text { TDDH- } \\
05\end{array}$ & 67874 & 11.90 & - & 7.49 & 7.611 & 22.64 & - & - & 48038 & - & 64 & 17.50 & 201 & 8 & 287 \\
\hline $\begin{array}{c}\text { TDDH- } \\
07\end{array}$ & 67872 & 0.26 & - & 8.18 & 16.31 & 22.64 & 1.73 & - & 4593 & 70 & 45 & 14.00 & 223 & 9 & 342 \\
\hline $\begin{array}{c}\text { TDDH- } \\
09\end{array}$ & 67875 & 4.28 & - & 5.74 & 13.05 & 21.40 & - & 2.79 & 44339 & - & 86 & 19.20 & 211 & - & 269 \\
\hline $\begin{array}{c}\text { TDDH- } \\
02\end{array}$ & 72491 & 0.59 & 1.67 & 5.41 & 14.68 & 17.05 & - & 5.80 & 3939 & 67 & - & 14 & 203 & - & 256 \\
\hline $\begin{array}{c}\text { TDDH- } \\
04\end{array}$ & 72000 & - & - & 5.20 & 13.59 & 17.05 & - & 3.56 & 41379 & - & 47 & 14 & 234 & 9 & 296 \\
\hline
\end{tabular}

\section{Conclusions}

The study area lies within the ArabianNubian Shield, corresponding to the mid Pan African Trondhjemite-TonaliteGranodiorite Suite. The granitoidal magma, probably assimilated magmatic source, derived from the subduction slab from melting of the lower part of the sediments, contains anomalous $\mathrm{Cr}$ and $\mathrm{V}$. The metasedimentary rock consisting of various types of schistose rocks, representing the older sequence in the area had been extruded by andesite with pillow lava. This indicates the subaqueous extrusion. Four deformational phases can be recognized in 
the study area, generally of brittle-ductile regime (D1-D4). D1 is characterized by F1 of regional extent, associated with the emplacement of granitoids magma and characterized by auriferous white quartz veinlets. D2-D4 might represent a single deformation event and might be transitional known as Keraf Shear Zone (KSZ). This deformation took place between 640 and 580Ma.This indicates that the granitoids pluton is older and the first separated hydrothermal solution took place prior to KSZ. The hydrothermal solution was separated at or after the crystallization of the granitoids magma; this is indicated by the injection of pegmatite stringers recorded in many exploration trenches and the aplite dyke along the marginal fissures of tonalite.

The foliation planes $\mathrm{S} 1$, were filled by hydrothermal quartz veinlets forming a stockwork deposit, with no sharp boundaries and can be mapped by sampling data based on anomalous gold content. The alteration zone at the contact of tonalite with metavolcano-sedimentary sequence, suggest a direct relation between tonalite and mineralization. The anomalous content of the elements $\mathrm{Au}, \mathrm{Ag}, \mathrm{Zn}, \mathrm{Pb}, \mathrm{Cu}$ and chlorite alteration indicates low sulphidation, related to the magmatic heat associated with granitoids intrusion.

\section{Recommendations}

The endo-contact zone is of regional extent and can be traced in both north and south directions, folded at the southern exploratory (Um Trambishi) while the other limb is exposed at areas west of the River Nile. Geochemical samples across the endocontact zone are recommended to locate anomalies along the whole of the prospected extension.

\section{Acknowledgements}

We would like to acknowledge the contributions of Mr. Amar Mustafa and
ElHadi Yahiya for their helpful discussion in the field work. This paper is a part of the exploration program of gold mineralization for Rida Mining Company, thanks to them for their permission to study this area and their full logistic support. Thanks to Prof. Badr el Din Khalil for his support and academic guidance.

\section{References}

Abdelslam,M.G.,Stern,R.J.,Copeland,P.,E IFaki,E.M,ElHur,B.,Ibrahim,F.M.,(1998). the Neoproterozoic Keraf Suture in NE Sudan: sinistraltranspression along the eastern margin of west Gondwana.J.Geol.106, 137-147.pp142.

BadrEl Din Khalil, (1973), Quantitative interpretation of secondary dispersion patterns of gold deposits in the Red Sea Hills-Sudan. Bull. No. 24,Geol.Research and Mineral Resources Department, Ministry of Industry and Mining,D.R. of the Sudan.

Giles, D.L., (1972). Petrology and mineralization of molybdenum-bearing alkali rock, Sierra Blanca, New Mexico: Geological Society of America Bulletin, v.83.p2129-2148.

John, D.A., (2001). Miocene and early Pliocene epithermal gold-silver deposits in the northern Great Basin, western United States: characteristics distribution and relation to magmatism. Economic Geology,v96. P 1827-1853.

Schilling, J.G., (1972). Rare earths in basalts: In the Encyclopedia of Geochemistry and Environmental Sciences. (Ed. R. W. Fair bridge), 1029-1039. 